\title{
Capital Flows, Interest Rates and Precautionary Behaviour: a model of Global Imbalances ${ }^{1}$
}

\author{
Marcus Miller ${ }^{2}$ and Lei Zhang ${ }^{3}$
}

July 2006

\begin{abstract}
A dynamic stochastic model of global equilibrium, where countries outside the US face higher risk than the US itself, predicts current account surpluses in the RoW and US deficits. With Loss Aversion, such precautionary savings can cause substantial 'global imbalances', particularly if there is an inefficient supply of global 'insurance'. In principle, lower real interest rates will ensure aggregate demand equals supply at a global level (though the required real interest may be negative). Low interest rates and high savings outside the US appear to be an efficient global equilibrium: but is this sustainable?
\end{abstract}

A precautionary savings glut appears to us to be a temporary phenomenon, destined for correction as and when adequate reserve levels are achieved. But if the process of correction is triggered by 'Sudden Stop' on capital flows to the US, might it not lead to the inefficient outcomes forecast by several leading macroeconomists? When precautionary saving is combined with financial panic, history offers no guarantee of full employment.

JEL Classification: D51, D52, E12, E13, E21, E44, F32.

Key words: stochastic dynamic general equilibrium, loss aversion, liquidity trap

\footnotetext{
${ }^{1}$ The paper has benefited by feedback from participants at the ESRC Workshop on "Global Imbalances" at Birkbeck College and a CRETA seminar at the University of Warwick, in particular from David Backus, Jonathan Cave, Jayasri Dutta, Sayantan Ghosal, Chris Meissner, Adam Posen, Herakles Polemarchakis and Neil Rankin. We would especially like to thank John Driffill, director of the ESRC World Economics and Finance Programme, for discussions and support and Neil Rankin for his comments, though we remain responsible for errors. The authors gratefully acknowledges the financial support of the ESRC, Marcus Miller under Grant No. RES-051-27-0125, and Lei Zhang under Grant No. RES-156-25-0032.

${ }^{2}$ Department of Economics, University of Warwick, and CEPR.

${ }^{3}$ Department of Economics, University of Warwick.
} 


\section{Introduction}

Current forecasts of global growth may be benign, but they pose interesting puzzles. If growth is expected to proceed at a healthy rate, why are real interest rates so low (Greenspan's conundrum)? If the current account US deficit proves unsustainable, how is it to adjust? Will this assisted by policy coordination ${ }^{4}$, as for the dollar in the 1980s: or can it be left to market forces? Before developing a simple global model to show how low real interest rates around the world and high savings outside the USA may be explained by attitudes towards risk, we outline some influential but contrasting views currently in circulation.

\section{Bretton Woods 2; Charles River reactions; and Dark matter}

To understand current events some argue that one needs to look back fifty years to the creation of the Bretton Woods system of fixed-but-adjustable exchange rates. Then, after WW II was over, the major economies of Europe pegged against the US dollar at exchange rates low enough to permit export-led recovery and a reconstitution of reserves. Now, in the $21^{\text {st }}$ century, it is not recovery from war but emergence from relative poverty that dictates the choice of regime; and the currency that is effectively pegged against the dollar is the Chinese remnimbi in what Dooley et al. (2004) call a revived Bretton Woods (hereafter BW2).

In their eyes, a policy of export-led growth, giving jobs to the millions who are leaving the land to seek jobs in manufacturing, makes good sense for China, now and for some time to come. And China is willing to hold the US securities that are financing the counterpart US deficits, a ready store of liquidity available to head off virulent financial panic of the type that swept East Asia in 1997/8. (If that was like bank run, as Jeff Sachs suggested at the time, China is now enabled to act as a regional lender-of-last-resort, and it is in fact party to regional swap arrangements to boost confidence, Kohlscheen and Taylor, 2006).

\footnotetext{
${ }^{4}$ As argued recently by the Governor of the Bank of England (King, 2006).
} 
Support for the viability of BW2 has been provided by Richard Cooper of Harvard University, a close observer of the Chinese scene, who argues that the investing domestic savings in dollars makes good sense for a country plagued with insecurity of property rights. This view effectively attributes to the US an 'exorbitant privilege' akin to monopoly in the issue of money as a liquid store of value: so the US is exporting security of ownership in exchange for cheap manufactures of goods.

Cooper's view has been provided with intriguing theoretical underpinning in a recent paper whose first author is at nearby MIT. Caballero et al. (2006) specify an infinite horizon OLG model of global demand and supply, where one group of countries is restricted in its the ability to capitalise on future earnings. They show how this reduces the group's effective wealth in global capital markets, lowering world interest rates and redistributing consumption towards countries that are not so restricted. Conditional on the existence of such capital market constraints, the constellation of low real rates and 'global imbalances' is an equilibrium phenomenon. The idea that agents whose budget constraints reflect current income rather than expected future flow will restrict their consumption accordingly sounds rather Keynesian; but, on their analysis, the restriction leads to lower interest rates not unemployment.

Rather than shackles that may hobble Asian economies, Hausmann and Sturzenegger (2005) appeal to the quasi-monopoly power of the US to explain the viability of the current regime ${ }^{5}$. The country may be running deficits as conventionally measured, but this is offset, they argue, by the acquisition of assets that are improperly accounted for. The missing elements, so-called dark matter, reflect quasi-rents in three areas: in the issuance of money in the form of dollar bills (seigniorage stricto sensu); in the provision of secure assets for a risky world; and in the supply of entrepreneurial know-how (adding 'goodwill' to US FDI).

The Transfer Problem; the Peso Problem; and the Risk of Recession

The sanguine view of a revived and relatively durable BW2 has been subjected to persistent and detailed criticism from academics, market watchers and think tanks,

\footnotetext{
${ }^{5}$ An analysis that may find support in Meissner and Taylor (2006).
} 
many located in the US itself. What then of those who see cracks in the edifice, signs of the demise of a regime created by peradventure and sustained by US deficits which would merit severe downgrades for any other sovereign borrower?

Obstfeld and Rogoff (2005), for example, judge the pattern of global imbalances to be unsustainable. To calibrate the adjustments needed to correct for this they appeal to an earlier historical episode - the transfer of resources from Germany to the Allies after WWI. Since the US is absorbing more than it produces (pace Hausmann and Sturzenegger), this will have shifted the real exchange rate, with the terms of trade moving in favour of US exports and the price of non-traded goods in the US rising relative to foreign counterparts. As and when the US curbs its absorption, the real exchange rate must adjust to reflect the shift of global demand. This may require a thirty percent devaluation of the dollar (a weighted average of a 10\% shift in the terms of trade and $40 \%$ shift in the relative price of non-traded goods, very approximately).

Their timely treatment is, however, subject to two criticisms. First, the model is static so it has little to say about the global interest rates. It is an account of general equilibrium in a global endowment economy, with intertemporal issues left to one side: the US deficit continues until, at some unspecified date, capital markets cry halt and the dollar falls to secure the appropriate reallocation of consumption. Second, in the process of adjustment it is assumed that national income constraints mimic those of a "transfer" problem; but it is far from clear why a unilateral decision by the US to reduce absorption will lead to expanded absorption elsewhere, especially if the trigger for the US adjustment is a Sudden Stop in capital flows to the world's largest economy.

Assuming that the end of BW2 will involve a significant dollar devaluation, this should surely have implications for the global pattern of interest rates. Indeed, as Jim Hanson has pointed out ${ }^{6}$, it implies existence of a 'peso problem'. If people expect a $30 \%$ dollar devaluation at some random time, then US assets should offer a devaluation premium. A peso problem in emerging market economies pushes their interest rates above the US rate: in this case, however, it is the rest of the world that

\footnotetext{
${ }^{6}$ As discussant at the conference on "Global Imbalances and Risk Management Has the center become the periphery?”, Madrid May 2006.
} 
adjusts. Given that the US sets rates, other countries have to pump in liquidity to lower theirs. This offers an alternative explanation for low rates to the capital constrained view of Caballero et al. (2006); and a prediction for US/non-US differentials that does not exist in their model.

Nouriel Roubini and Brad Setser have expressed persistent doubts as to how long current imbalances can be sustained, Setser (2006). Their scepticism is shared by Fred Bergsten and his colleagues at the IIE who have been calling for a dollar devaluation for some time, Bergsten and Williamson (2004). Their calculation of a multilateral adjustment of exchange rates implicitly rejects the view taken in some quarters that 'the Euro is no part of the problem, so it is no part of the solution'. Insofar as these calculations assume no collapse of global demand they may like Obstfeld and Rogoff be assuming effective 'transfers' (or they may be assuming successful monetary stabilisation of world demand). Martin Wolf is perhaps the most widely read proponent of the view that substantial rebalancing of global demand and adjustment of exchange rates is necessary for sustainability.

It is a matter of history that the transfers mandated by the victorious allies after WWI were followed not by smooth economic adjustment but by falling demand and, ultimately, by the Great Depression. This may well be the historical precedent that prompts the warnings of possible disaster made Barry Eichengreen an expert on the Gold Standard and its collapse. He and Yung Park of Seoul University forsee a Sudden Stop in the lending to the US leading to collapse in the dollar with rising interest rates to prevent overshooting (and an attendant collapse of asset prices, especially housing). In their view, rising rates and falling demand in the US will lead to deficient demand at a global level, (Eichengreen and Park, 2006).

Table 1 provides a brief summary of these views classified by whether the need to adjust the pattern of global demand and/or the need to adjust the dollar exchange rate is seen as a major problem. Outright optimism, which sees neither as a problem, appears in the upper left right corner, represented by Hausmann and Sturzenegger for whom Dark Matter dispels all doubts - and by Backus et al. (2006). Pessimists, who see both issues as needing adjustment appear in the bottom right, including Setser (2006), Eichengreen and Park and Martin Wolf. 


\begin{tabular}{|c|c|c|c|}
\hline & $\begin{array}{l}\text { No exchange rate } \\
\text { problem }\end{array}$ & $\begin{array}{l}\text { Some dollar } \\
\text { overvaluation }\end{array}$ & Unsustainable overvaluation \\
\hline $\begin{array}{l}\text { No imbalance of } \\
\text { demand }\end{array}$ & $\begin{array}{l}\text { H and S: "Dark } \\
\text { Matter" } \\
\text { Backus et al. }\end{array}$ & & \\
\hline $\begin{array}{l}\text { Some demand } \\
\text { imbalance }\end{array}$ & $\begin{array}{l}\text { Cooper } \\
\text { Caballero et al: } \\
\text { "Constrained } \\
\text { Equilibrium" }\end{array}$ & & $\begin{array}{l}\text { Dooley and Garber: "BW2" } \\
\text { Obstfeld and Rogoff: "The } \\
\text { Transfer Problem" }\end{array}$ \\
\hline $\begin{array}{l}\text { Unsustainable } \\
\text { demand } \\
\text { imbalance }\end{array}$ & & & $\begin{array}{l}\text { Roubini and Setser } \\
\text { Bergsten and Williamson } \\
\text { Eichengreen and Par } \\
\text { Martin Wolf }\end{array}$ \\
\hline
\end{tabular}

Table 1 Global imbalances and the dollar: differing assessments

Between these poles are two other groups. First Dooley and Garber with their BW2 perspective, where benign US deficits sustainable for some time to come. Second those who see the savings glut as sustainable long-term for institutional reasons: this 'Charles River School' includes both Cooper and Caballero et al.

The paper is structured as follows. Using Fisherian intertemporal approach, Section 2 briefly looks at the savings when there is no uncertainty. Section 3 develops the benchmark model of general equilibrium with uncertainty. Risk in the RoW can be effectively shared with the US without substantial surpluses or deficits. Section 4 introduces loss aversion leading to substantial precautionary saving and US deficit. In the absence of complete markets, substantial risk can lead to negative interest rates. Section 5 discusses whether strategic factors may lead to the limitations of insurance markets. Section 6 discusses sustainability and the temporary nature of the precautionary savings. Section 7 considers the possible emergence of Keynesian equilibrium due to a Liquidity Trap and/or a 'Sudden Stop' in capital flows. Section 8 concludes that a savings glut could lead to deficient world demand if it is combined with financial panic that prevents the US from acting as "consumer of last resort". 


\section{External Imbalances and Irving Fisher}

Irving Fisher viewed savings and investment decisions from the perspective of optimising consumption over time ${ }^{7}$ : and applying this perspective to countries involved in international trade has led to the now-popular intertemporal approach to the balance of payments. As Obstfeld and Rogoff (1996, Chapter 1) express it, "Much of the macroeconomic action in an open economy is connected with its intertemporal trade, which is measured by the current account of the balance of payments".

Before introducing our general equilibrium approach, which includes intertemporal issues as well as those involving risk, we sketch three variants of the neo-Fisherian perspective that bear on the current debate. First the that current account imbalances may reflect international differences in growth rates, as suggested by Backus et al. (2006); second that, with no growth differentials, imbalances may reflect capital market constraints, as in Caballero et al. (2005); a third, closely-related possibility is that behaviour may be reflecting insecure property rights in the RoW, the Cooper hypothesis.

These can be illustrated simply using the Fisher diagram, Figure 1.

First let the endowment of the US be at point A and that of the rest of the world at A', the former exhibiting high growth and the latter no growth. Given identical tastes, these growth differentials provide incentives for inter-temporal trade. The US can smooth consumption by consuming RoW saving at interest rates lying between the pure rate of time-preference shown at $A^{\prime}$ and the much high rate of intertemporal substitution at point A (where the slope of the indifference curve also reflects the high growth rate). The equilibrium trade vectors are shown by $\mathrm{A}^{\prime} \mathrm{B}$ and $\mathrm{AC}$ and both countries end up consuming on the same ray from the origin. We believe this captures a key element of the global equilibrium perspective of Backus et al. (though it is admittedly something of a caricature as growth differentials are taken as exogenous).

\footnotetext{
${ }^{7}$ As, in a full employment context, did Keynes and Ramsey (1928).
} 
Next assume by contrast that both countries have identical endowment at point A. While the US consumes with the appropriate intertemporal budget constraint, let the RoW be constrained to lower budget line passing through A' as might be the case if capital markets fail to take due account of future endowments. The consumption and savings in period 1 will be precisely the same as for the case of growth differentials. Could this represent the capital-constrained perspective of Caballero et al? (Probably not, because it would not be sensible for the RoW to save knowing that it is about to receive the same endowment as the US!)

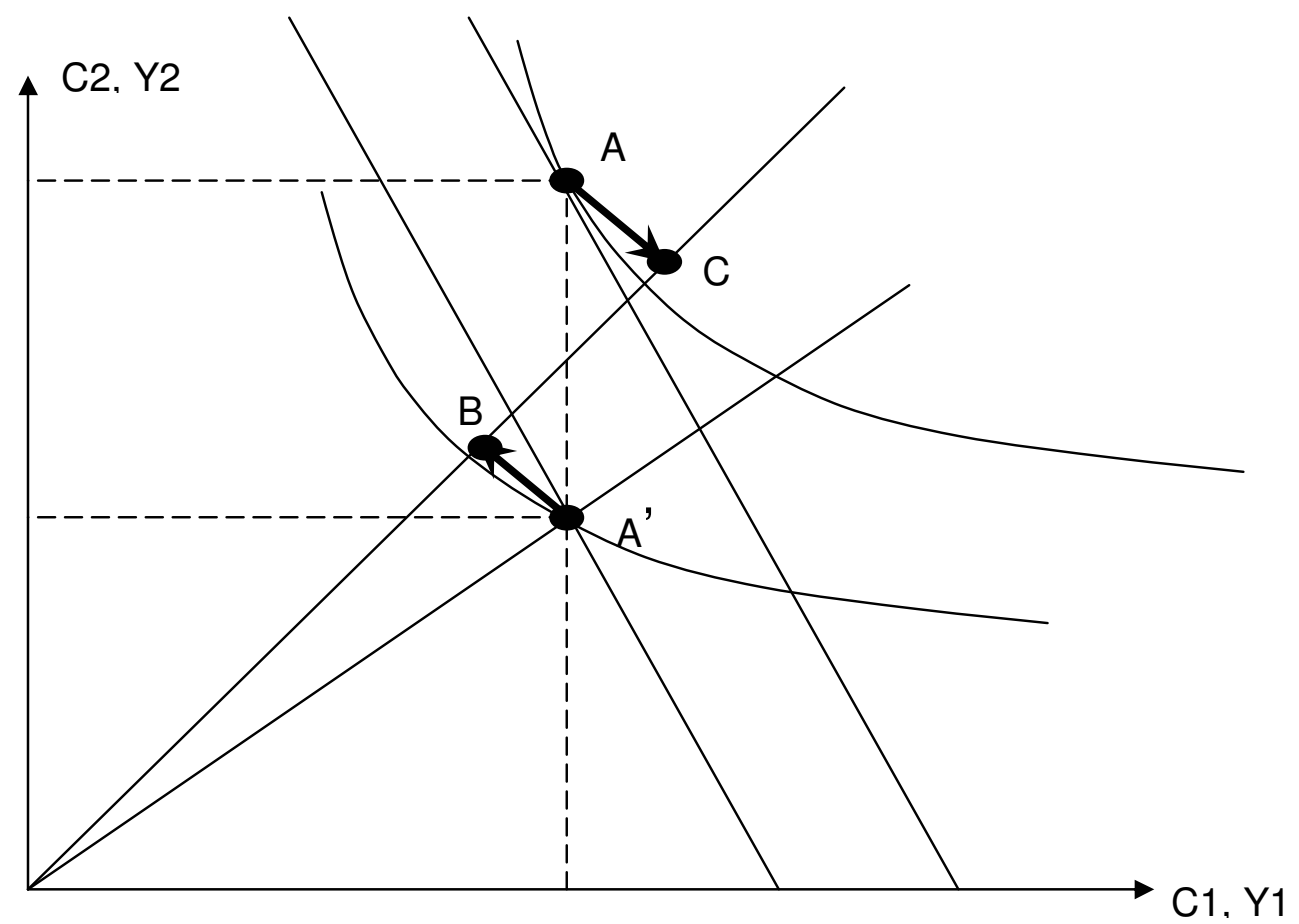

Figure 1. Fisher diagram: differentials in growth, wealth constraint and pessimism

But what if consumers in the RoW are not sure that they will secure the extra outputbecause of ill-defined property rights, as Cooper says is true in China? Then they might act 'as if' their expectations of the growth in the RoW were unduly pessimistic --- as if they expected output in RoW to be stationary, for example. In which case, despite the fact that both countries have identical endowments at point $\mathrm{A}$, insecure ownership might lead to the same high savings in RoW and low global interest rates as predicted Backus et al. 
These inter-temporal accounts are essentially deterministic: would a stochastic specification have something more to offer? This is what we explore next, first with standard (logarithmic) preferences and then with the introduction of loss aversion.

\section{A General Equilibrium approach}

To incorporate risk, we use a simplified dynamic stochastic general equilibrium (DSGE) model in the tradition of Mas-Colell et al (1995) and Obstfeld and Rogoff (1996). This stylised one good model has two time periods, two states of nature and two countries; and we use the appellation Home country to denote the US and Foreign to denote the Rest of the World (RoW) treated as a bloc. The framework not much different from that used earlier in Miller et al $(2005,2006)$ to study global finance and the US New Economy, though the endowment pattern reflects the traditional situation where the US invests in risky assets and supplies safety and security in exchange (Hausmann and Sturzenegger, 2005).

Rather than postulating growth differentials, with low growth for the RoW accounting for low world real interest rates and large US deficits, we assume identical expected growth but differential risk. Specifically growth prospects in RoW have greater volatility than for the US. Though this does not have a great impact in a standard general equilibrium framework, results change when downside risk is aggravated by a form of Loss Aversion. (The utility of consumption in period 2 which lies below that reached in the previous period is sharply discounted.) In a stochastic environment, the resulting risk sensitivity can lead the RoW to acquire substantial insurance; and to act 'as if' it underestimates the mathematical expectation of growth.

When the relevant insurance is not be available (or the provision is not credible), the RoW can always 'self-insure' - saving instead of swapping financial promises. So the desire to limit downside risk can make the RoW act 'as if' it has very low time preference as we show in numerical outcomes below. Combining inadequate insurance with Loss Aversion provides a ready explanation for low interest rates, the US deficit and high RoW savings. 
To put this in context, consider the case of China. After what happened to many East Asian countries in $1997 / 8^{8}$, it is clear that interruptions to trend growth are perfectly possible: and the rampant Chinese Dragon may be no more immune to shocks than were the Asian Tigers. In the words of Peter Nolan (2004, pp48-49):

Today, the Chinese economy is growing fast, but the lesson from the past, especially the Asian Financial Crisis, is that perceptions can change overnight. China is today the last remaining large 'Growth story' in the world; it already has a huge 'bubble' of FDI, with the largest FDI inflows of any economy in the world... It is easy to imagine how the bubble might burst, and the flow of capital be reversed, with huge potential destabilizing consequences for the economy and society. There would then be a full-blown 'Chinese Financial Crisis'. A central goal of policy must be to avoid such an outcome. [Italics added]

If there is concern that consumption on the downside should not fall relative to past levels, China can of course seek insurance by selling FDI and buying US government bonds: and it can also seek to self-insure by acquiring US bonds via the current account. If, for any reason, the first option is limited, then self-insurance will be seen as the only way to avoid an unappealing prospect - the prospect, perhaps, of humiliation like that suffered by its near neighbour South Korea in 1997/1998 when it had to go cap in hand to the IMF and G7 and sacrifice sovereignty to get the financial support it needed in the crisis.

These considerations suggest that strategic factors may play a role that is not captured in the competitive framework we use here ${ }^{9}$ : that some sort of insurance market game may be in process. This is discussed briefly in section 4 below.

\subsection{Benchmark Case}

\footnotetext{
${ }^{8}$ when, in the crisis, trend growth rates effectively changed sign

${ }^{9} \mathrm{We}$ are grateful to Sayntan Ghosal for this observation. It carries the implication that the is 'unrelentingly competitive' Incomplete General Equilibrium with default studied by Dubey et al (2005) is not really appropriate here.
} 
The pattern of endowments assumed is indicated in Table 2. Both blocs are endowed with one unit at time one. In expected terms each bloc grows at the rate $g$, say three percent. In the absence of uncertainty each bloc would consume its endowment and, with log utility, real interest rates would equal growth rate plus the pure rate of time preference. If the latter were, say, 1.5 percent, this would imply the global real interest rates of $4.5 \%$.

With uncertainty, consider the case where future endowments for ROW can take one of two values: high and low, with a standard deviation of $\sigma$ around the mean rate of growth. (For convenience, each of the two outcomes is treated equi-probable; and in simulations $\sigma$ varies between 3 to $12 \%$.)

\begin{tabular}{|c|c|c|c|}
\hline & USA & \multicolumn{2}{|c|}{ ROW } \\
\hline & & $\begin{array}{c}\text { High (with } \\
\text { probability } \pi \text { ) }\end{array}$ & $\begin{array}{c}\text { Low (with } \\
\text { probability } 1-\pi)\end{array}$ \\
\hline Period 1 & $Y_{1}=1$ & $Y_{1}^{*}=1$ & $Y_{1}^{*}=1$ \\
\hline Period 2 & $Y_{2}(1)=Y_{2}(2)=1+g$ & $Y_{2}^{*}(1)=1+g+\sigma$ & $Y_{2}^{*}(2)=1+g-\sigma$ \\
\hline
\end{tabular}

Table 2 The pattern of endowments

To understand the pattern of savings and world real interest rates, we first present benchmark results where the complete set of Arrow-Debreu securities can be traded. Later we will look at how these results may change if the set of securities is restricted or preferences modified. For simple exposition of the benchmark results, we assume representative consumers in both countries share identical preferences. Home country's lifetime utility is given by

$U\left(C_{1}, C_{2}(\cdot)\right)=\ln \left(C_{1}\right)+\beta\left[\pi \ln \left(C_{2}(1)\right)+(1-\pi) \ln \left(C_{2}(2)\right)\right]$

where $\beta$ is time preference, $C_{1}$ and $C_{2}(\cdot)$ are period 1 and period 2 consumption respectively. The budget constraint of the Home country is given by

$C_{1}+q(1) C_{2}(1)+q(2) C_{2}(2)=Y_{1}+q(1) Y_{2}(1)+q(2) Y_{2}(2) \equiv W$ 
where $q(s)>0(s=1,2)$ are Arrow prices measured in period 1 sure consumption, and $W$ is the present value of Home country's total wealth.

Given Arrow prices, Home's optimal consumption implied by its first order conditions are simply

$$
\begin{aligned}
& C_{1}=\frac{W}{1+\beta} . \\
& C_{2}(1)=\frac{\beta \pi}{q(1)} C_{1} \\
& C_{2}(2)=\frac{\beta(1-\pi)}{q(2)} C_{1}
\end{aligned}
$$

Those for the Foreign country follow the same forms.

Applying equilibrium conditions, that total consumption in each period and state equals the corresponding total endowment, determines the equilibrium Arrow prices and real interest rates as follows:

$$
\begin{aligned}
& q(1)=\pi \beta Y_{1}^{W} / Y_{2}^{W}(1) \\
& q(2)=(1-\pi) \beta Y_{1}^{W} / Y_{2}^{W}(2) \\
& \sum_{s} q(s)=1 /(1+r)
\end{aligned}
$$

where superscript $\mathrm{W}$ indicates world endowment. The pattern of consumption is obtained by substituting (6) and (7) into (3), (4) and (5).

With the endowments specified in Table 2, Foreign has an incentive to save in period 1. This is evident from a comparison of Foreign wealth relative to Home wealth. Note that

$W^{*}=(W-(q(2)-q(1)) \sigma)<W$

where $\sigma$ is the standard deviation of the Foreign endowment and $q(2)>q(1)$.

Because Foreign wealth is relatively lower, so is consumption, i.e. 
$C_{1}^{*}=W^{*} /(1+\beta)<W /(1+\beta)=C_{1}$. So Foreign would save and Home would run a current account deficit. Clearly the more volatile is Foreign's endowment is in period 2 (higher $\sigma$ ) the higher will be its period 1 savings. But with log utility and efficient provision of 'insurance', the savings effects are distinctly modest, as will be seen in Table 3.

How securities markets provide this insurance is indicated in Figure 2, an Edgeworth box diagram as in Mas-Colell et al (p.593, 1995), where for convenience we ignore the effect of the first period savings (which turn out to be very small, see Table 3). Outcomes for the high payoff state are on the horizontal and for the low payoff state on the vertical, and utility for the RoW is measured from the lower left corner while that for US is measured from the upper right. Identical probability assessments and utility functions imply that the contract curve is the diagonal in the figure. ${ }^{10}$ The autarky endowment point is at $A$, where for the US --- identical endowments in both states --- this lies on the 45-degree line measured from the upper right corner. For the RoW, however, disparity in the endowment between the two states means that it lies to the right of the 45-degree line drawn from the bottom left corner. Note that, given $\pi=1 / 2$, the indifference curve $I^{*}$ for the US has a slope of -1 at point $A$. Ignoring the effect of the first period savings on reallocating entitlements, general equilibrium consumption is shown at point $C$ (on the contract curve) where the trading vector $\mathrm{AC}$ has a slope of less than 1 in absolute value. [Specifically, the slope in absolute terms is $|q(1) / q(2)|<1$, reflecting of the relative abundance of goods in high state.]

\footnotetext{
${ }^{10}$ The assumption of identical utility is more restrictive than Mas-Colell et al (p.693, 1995) where the contract curve is non-linear.
} 


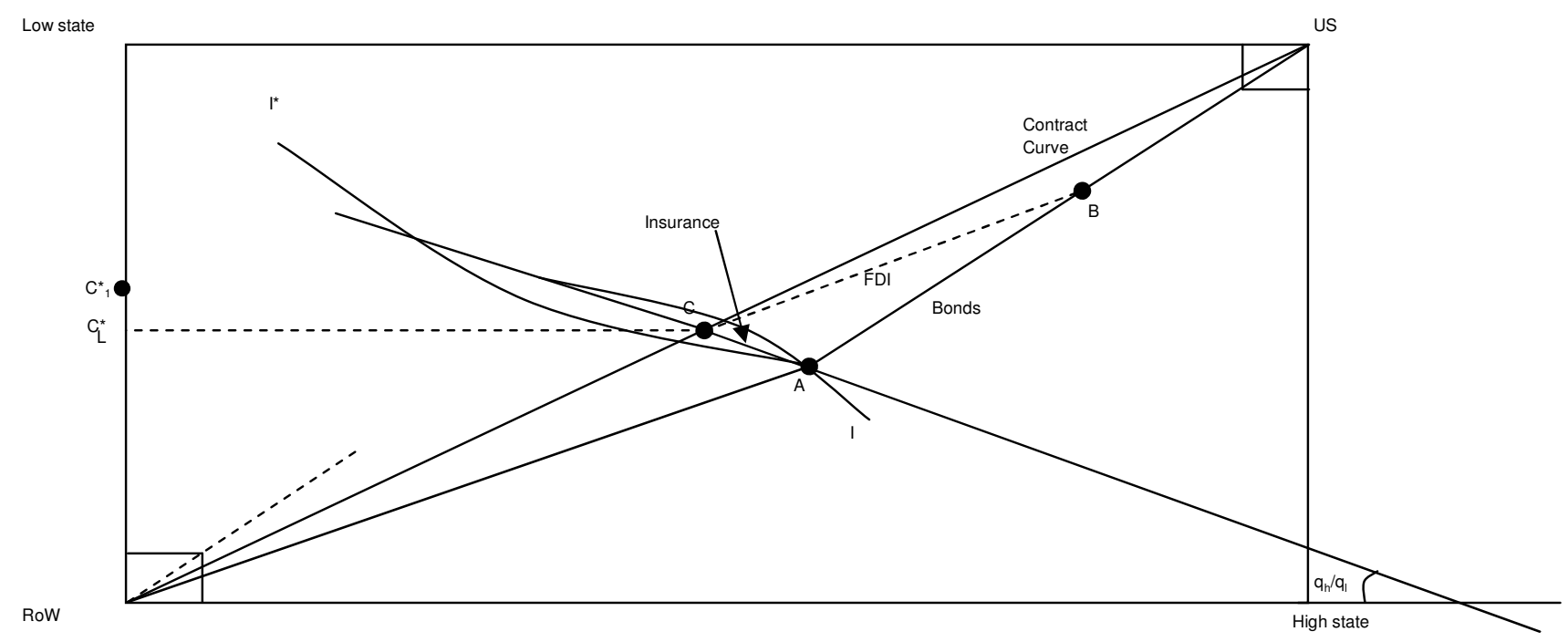

Figure 2: RoW buys "safety".

Given the asymmetry of global endowments, consumption risk in the RoW is not diversified away: but it is shared as shown in the Figure, which involves the RoW exchanging claims on output in state 1 for claims in state 2 at the relative price indicated by the slope of AC. In the absence of Arrow securities, what assets might sustain this equilibrium? In terms of safe assets issued by the US (measured along the 45-degree line) and risky assets issued by the RoW (along line RoWA), consumption at $\mathrm{C}$ may be achieved by the sale of bonds from the US (vector $\mathrm{AB}$ ) in exchange for GDP bonds of the RoW (labelled FDI in the Figure, see vector BC). (Consider sales of US government securities in exchange for FDI in China, for example; or see Griffith-Jones and Sharma (2006), Griffith-Jones and Shiller (2006) for discussion of GDP bonds.)

How does aggregate risk affect global interest rates and current account imbalances? Not very much, as is shown in Table 3 using parameter values of $\beta=0.985, \pi=1 / 2$, and endowments from Table 2, where average growth is $3 \%$ in both blocs.

\begin{tabular}{|l|l|l|}
\hline$\sigma$ & World Interest Rates & US deficit/RoW savings \\
\hline $3 \%$ & $4.5 \%$ & $0.01 \%$ \\
\hline $6 \%$ & $4.5 \%$ & $0.04 \%$ \\
\hline $12 \%$ & $4.2 \%$ & $0.2 \%$ \\
\hline
\end{tabular}

Table 3. Savings and real interest rates in the benchmark case. 
Evidently, stochastic endowments for the RoW do lead to some lowering of world interest rates and some increase in the US deficit as the theory predicts: but with log preferences the quantitative effects are very small. Increasing the standard deviation from $3 \%$ to $12 \%$, for example, only increases the US deficit by one fifth of a percentage point of GDP; and it shaves a mere 30 basis points off the world interest rate.

\subsection{Equilibrium with no "insurance"}

What if the only asset traded between the two countries is a bond which has the same payoff in both states in period 2? In the absence of insurance possibilities, the RoW will save more in period 1 to avoid potential utility losses were it to consume its unequal endowments in period 2, and the extra savings will bring down the global rate of interest. This can be shown as follows.

Denote $S$ the first period saving by the Home country (the amount of bonds purchased), its optimal level is determined by the solution to the following problem:

$\operatorname{Max}_{S}\left\{\ln \left(C_{1}\right)+\beta\left[\pi \ln \left(C_{2}(1)\right)+(1-\pi) \ln \left(C_{2}(2)\right)\right]\right\}$

subject to

$C_{1}=Y_{1}-S$

$C_{2}(1)=Y_{2}(1)+(1+r) S$

$C_{2}(2)=Y_{2}(2)+(1+r) S$

where $(1+r)$ is the gross real interest rates.

As $Y_{2}(1)=Y_{2}(2)=Y_{2}$, the optimal saving implies the period 1 consumption

$C_{1}=\frac{1}{1+\beta}\left(Y_{1}+\frac{Y_{2}}{1+r}\right)$

One can solve for a similar problem for the Foreign country to yield its period 1 consumption

$C_{1}^{*}=Y_{1}-\frac{-\xi+\sqrt{\xi^{2}-4(1+\beta) \zeta}}{2(1+\beta)}$

where 
$\xi=Y_{2}^{*}(1)+Y_{2}^{*}(2)+\beta\left[\pi Y_{2}^{*}(2)+(1-\pi) Y_{2}^{*}(1)\right]-\beta(1+r) Y_{1}$

$\varsigma=Y_{2}^{*}(1) Y_{2}^{*}(2)-\beta(1+r) Y_{1}\left[\pi Y_{2}^{*}(2)+(1-\pi) Y_{2}^{*}(1)\right]$

Imposing equilibrium condition

$C_{1}+C_{1}^{*}=2 Y_{1}$

yields the following fixed point condition for real interest rates

$\left(\frac{Y_{2}}{1+r}-\beta Y_{1}\right)^{2}+\xi\left(\frac{Y_{2}}{1+r}-\beta Y_{1}\right)+(1+\beta) \varsigma=0$

Equations (9) and (10) are used to generate numerical results in Table 4.

\begin{tabular}{|l|l|l|}
\hline$\sigma$ & World Interest Rates & RoW Saving/US deficit \\
\hline $3 \%$ & $4.5 \%$ & $0.02 \%$ \\
\hline $6 \%$ & $4.4 \%$ & $0.08 \%$ \\
\hline $12 \%$ & $3.9 \%$ & $0.34 \%$ \\
\hline
\end{tabular}

Table 4. Savings and real interest rates without insurance.

The RoW saving as percentage of GDP (and the US deficit) is twice as large as in the benchmark case, but it still remains very small even when standard deviation of the shock to its endowment rises to $12 \%$. The effect on interest rates is more pronounced they fall by 60 basis points, to less than $4 \%$, as the standard deviation increases from 3 to $12 \%$. So, with log utility, it appears that eliminating insurance does not predict a savings glut in the RoW.

\section{Loss aversion, high savings and low global real interest rates}

\subsection{Loss aversion with a complete set of Arrow securities}

In this section, we modify the preferences of the RoW by incorporating two elements from Prospect Theory (Kahneman and Tversky, 1979): namely, reference dependence and loss aversion. We assume that consumption achieved in the previous period acts as a reference in the current period, so the measurement of utility depends on whether 
there is a "loss" or a "gain" in current consumption relative to this reference. To capture loss aversion, we assume that, close to the reference point, the increase in utility of a unit "gain" in current consumption (relative to the reference) is much smaller than the decrease in utility of a unit "loss" in current consumption.

Specifically, let the utility of state i consumption be defined as

$$
u\left(C_{2}^{*}(i)\right)=\left\{\begin{array}{llc}
\ln \left(C_{2}^{*}(i) / C_{1}^{*}\right) & \text { if } \quad C_{2}^{*}(i) \geq C_{1}^{*} \\
\lambda \ln \left(C_{2}^{*}(i) / C_{1}^{*}\right) & \text { if } \quad C_{2}^{*}(i)<C_{1}^{*}
\end{array}\right.
$$

where $\lambda>1$ indicates the degree of loss aversion. (Note that the utility measure becomes negative for consumption below reference level.)

To make the following treatment tractable, we consider an extreme case of loss aversion, namely, $\lambda \rightarrow+\infty$. Under this simplification, (11) is equivalent to constraints $C_{2}^{*}(i) \geq C_{1}^{*}$

The procedure used here, of imposing the constraint that next period's consumption in any state of the world should not fall below consumption in the current period, could also be viewed as an extreme form of habit formation as widely used in macroeconomic models. Chari, Kehoe and McGrattan (2002), in their attempts to determine whether sticky prices can lead to volatile and persistent real exchange rate movements, for example, assume in one experiment that the utility from consumption depends not on current consumption but its level relative to a fraction of last period's aggregate consumption. A similar formulation has also been used by Campbell and Cochrane (1999), Carroll, Overland, and Weil (2000), Ravn, Schmitt-Grohe, and Uribe (2004). As Carroll et al show, with this form of habit-persistence in consumption, higher growth may lead to higher saving.

In what follows, we show that loss aversion can also increase savings, but only if consumption would otherwise have fallen below the reference trigger. With complete contingent securities, Home optimal consumption is derived in the same way as in Section 2.1. But Foreign's optimal consumptions are solutions to the following problem:

$$
\operatorname{Max}_{C_{1}^{*}, C_{2}^{*}(i)}\left\{\ln \left(C_{1}^{*}\right)+\beta\left[\pi \ln \left(C_{2}^{*}(1)\right)+(1-\pi) \ln \left(C_{2}^{*}(2)\right)\right]\right\}
$$


subject to the budget constraint

$$
C_{1}^{*}+q^{L A}(1) C_{2}^{*}(1)+q^{L A}(2) C_{2}^{*}(2)=Y_{1}^{*}+q^{L A}(1) Y_{2}^{*}(1)+q^{L A}(2) Y_{2}^{*}(2) \equiv W^{*}
$$

and (12).

How loss aversion in the Foreign country change the equilibrium prices and allocation? We summarise these results in the following propositions.

Proposition 1. If $\sigma \leq 2 g$, equilibrium prices and allocation are the same as those in Section 2.1.

Proof: See Appendix A.

Note that with complete Arrow securities, both countries can share risks. This risksharing means that both countries consume more or less equal proportions of the aggregate state endowment. So if the standard deviation of Foreign endowment in period 2 is small, the Foreign country is effectively insured against low consumption in the bad state. Therefore, no additional saving is required.

Proposition 2. For the endowment structure given in Table 2, if $\sigma>2 g$, then

(1) $q^{L A}(1)>q(1)$ and $q^{L A}(2)>q(2)$;

(2) $q^{L A}(2) / q^{L A}(1)>q(2) / q(1)$;

(3) $r^{L A}<r$;

(4) $C_{1}^{*}(L A) \leq C_{1}^{*}$.

Proof: See Appendix B.

Results in Proposition 2 are quite intuitive. If the standard deviation of period 2 Foreign endowment is large, simple risk sharing is not sufficient to ensure that the consumption in the bad state remains above the reference level for the Foreign country. So loss aversion increases Foreign country's demand for insurance in period 2. As this raises the relative price $q^{L A}(2) / q^{L A}(1)$, the Foreign also increases savings as a substitute for high cost insurance. (Note that period 1 savings for the Foreign 
country not only act as a substitute for insurance but also reduce the reference consumption in period 2 , making the constraint less likely to bind.)

Suppose we allow Foreign country to have a different parameters for time preference, $\beta^{\prime}$, and the subjective probability parameter, $\pi^{\prime}$, while keeping those of the Home country as before, can we replicate the outcomes in Proposition 2 without evoking the assumption of loss aversion? The results for this "as if" exercise are given in the following proposition.

Proposition 3. For a set of parameters $\left\{\beta, \pi ; \beta^{\prime}, \pi^{\prime}\right\}$ (and given restriction on endowments as in Proposition 2) to replicate the equilibrium results in Proposition 2, it is sufficient that

(1) $\pi^{\prime}=\frac{\beta \pi\left(1+q^{L A}(2)\right)}{(1+\beta) q^{L A}(2)+\beta \pi}<\pi$

(2) $\beta^{\prime}=\frac{(1+\beta) q^{L A}(2)+\beta \pi}{1+\beta(1-\pi)}>\beta$

Proof: See Appendix C.

Proposition 3 indicates that the effects of introducing loss aversion on the part of the Foreign country will (when the constraint is binding) be to increase its perceived pessimism $\left(\pi^{\prime}<\pi\right)$ and to make it more forward-looking $\left(\beta^{\prime}>\beta\right)$.

The quantitative significance of such loss aversion on real interest rates and savings are given in the Table below. With the standard deviation of up to $6 \%$, the constraint is not binding, so the real interest rates and savings are the same as in Table 3. But the effect of loss aversion becomes apparent when the standard deviation increases to $12 \%$ or $18 \%$ : this generates a substantial increase in the RoW savings and a marked fall in the global interest rates. As a consequence US deficit can rise by more than $2 \%$ of GDP as a $3 \%$ fall of the real interest rates encourage US consumption. 


\begin{tabular}{|l|l|l|l|l|l|}
\hline$\sigma$ & $\begin{array}{l}\text { World } \\
\text { Interest Rates }\end{array}$ & $\begin{array}{l}\text { RoW Saving/ } \\
\text { US deficit }\end{array}$ & $\begin{array}{l}\text { Loss } \\
\text { aversion } \\
\text { constraint }\end{array}$ & $\beta^{\prime} / \beta$ & $\pi^{\prime} / \pi$ \\
\hline $3 \%$ & $4.5 \%$ & $0.01 \%$ & Not binding & 1 & 1 \\
\hline $6 \%$ & $4.5 \%$ & $0.04 \%$ & Not binding & 1 & 1 \\
\hline $12 \%$ & $3.1 \%$ & $1.2 \%$ & Binding & 1.03 & 0.98 \\
\hline $18 \%$ & $1.5 \%$ & $2.5 \%$ & Binding & 1.07 & 0.97 \\
\hline
\end{tabular}

Table 5. Savings and real interest rates under loss aversion.

To see how loss aversion can impact on global equilibrium, we redraw the Edgeworth box used earlier to show the general equilibrium outcomes and how they may be replicated by lower time preference (higher $\beta$ ) and greater pessimism (lower $\pi$ ).

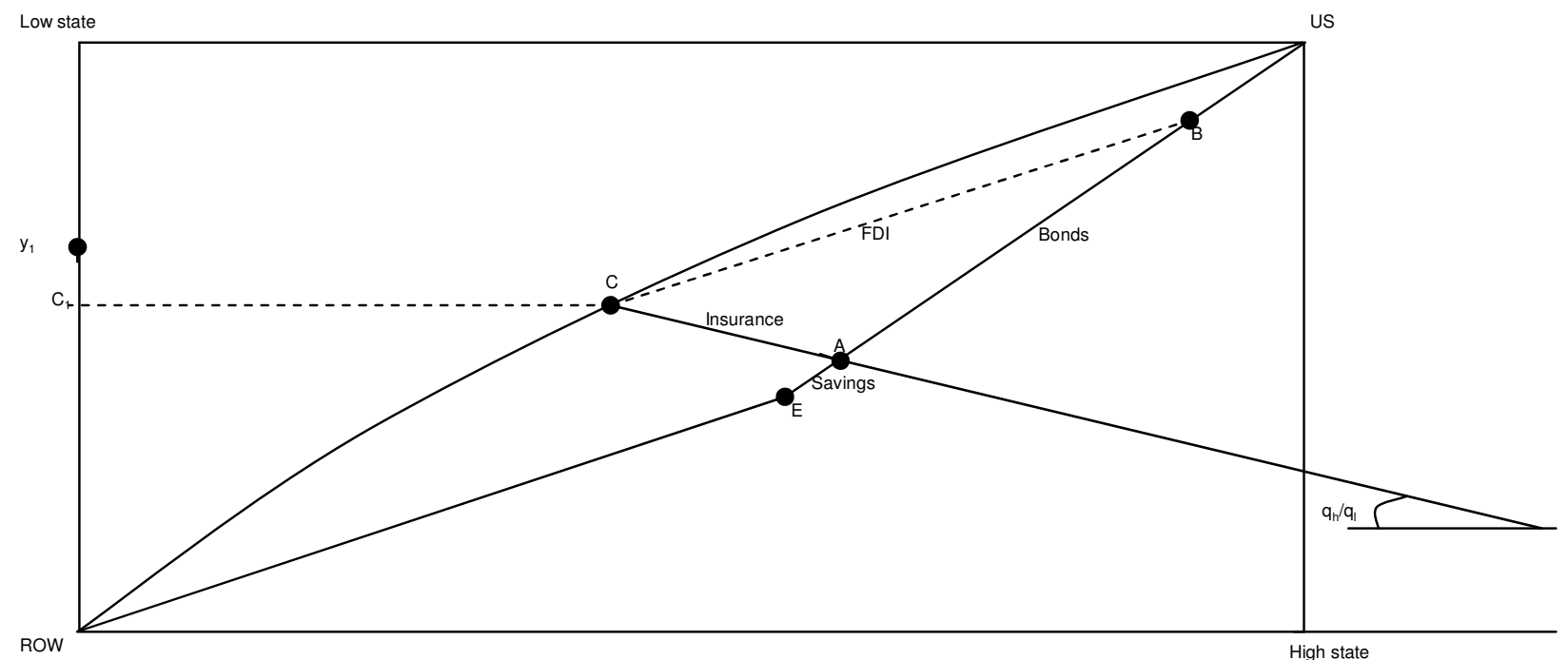

Figure 3: Savings and insurance with Loss Aversion; it's 'as if' time preference has fallen and pessimism has increased in RoW.

With the same axis of measurement the 2 period endowment is now indicated at $\mathrm{E}$ and consumption at point $\mathrm{C}$. The extra demand for insurance by RoW, calibrated by an increase in pessimism as $\pi^{\prime} / \pi$ falls in the RoW, has the effect of making the contract curve concave downwards as shown in the Figure. The extra demand for savings calibrated by the increase in $\beta^{\prime} / \beta$ in the RoW has the effect of shifting second period endowments from E to A. From A an assets swap of bonds for FDI (i.e. 
insurance along the vector AC) allows for consumption at point C. Imposing the loss aversion constrain has ensured that the combination of extra savings and insurance has lifted consumption in the low state $\mathrm{C}_{\mathrm{L}}$ to match first period consumption, shown as $\mathrm{C}_{1}$ on the left-hand axis.

\subsection{Loss aversion with no insurance}

Results from the section above show how loss aversion can significantly increase savings and reduce world interest rate. This is the case even if both countries can share risk in the second period. If countries are restricted to trade only bonds, can the real interest rates fall even further and become negative? In what follows, we first summarise results for this bond-only case in the propositions below, and then go on to illustrate its quantitative significance using numerical examples.

Proposition 4. For $\sigma \leq g$, the equilibrium real interest rates and consumption allocations are the same as those in Section 3.2.

For $\sigma>g$, the constraint $C_{2}^{*}(2) \geq C_{1}^{*}$ binds, and the equilibrium real interest rate is

$1+r=\frac{-\psi+\sqrt{\psi^{2}+4 \beta Y_{1} Y_{2} /(1+\beta)^{2}}}{2 \beta Y_{1} /(1+\beta)}$

where $\psi=\beta Y_{1} /(1+\beta)+Y_{1}-Y_{2}^{*}(2)-Y_{2} /(1+\beta)$.

The consumption allocation for the Foreign country is given by

$C_{2}^{*}(1)=Y_{2}^{*}(1)+(1+r)\left(Y_{1}-Y_{2}^{*}(2)\right) /(2+r)$

$C_{2}^{*}(2)=C_{1}^{*}=\left[(1+r) Y_{1}+Y_{2}^{*}(2)\right] /(2+r)$

and the consumption allocation for the Home country can be obtained simply by using the market clearing conditions.

Proof: For $\sigma \leq g$, one can show that $C_{2}^{*}(2) \geq C_{1}^{*}$, so real interest rates and consumption allocation in Section 3.2 still constitute the equilibrium solution. For $\sigma>g$, however, solutions in Section 3.2 violate the constraint $C_{2}^{*}(2) \geq C_{1}^{*}$. Imposing binding constraint yields the optimal consumption for the Foreign country as in (15) and (16). The optimal consumption for the Home country, derived in the same way as in Section 3.2, gives 


$$
\begin{aligned}
& C_{1}=\frac{1}{1+\beta}\left(Y_{1}+\frac{Y_{2}}{1+r}\right) \equiv \frac{W}{1+\beta} \\
& C_{2}(1)=C_{2}(2)=\frac{\beta(1+r) W}{1+\beta}
\end{aligned}
$$

Using market clearing condition $C_{1}+C_{1}^{*}=2 Y_{1}$ one arrives at the equilibrium real interest rates represented by (14). Using (14), one can back out the equilibrium consumption for both Home and Foreign countries.

One thing worth noting from the above proposition is that the bond-only case generates a binding constraint $C_{2}^{*}(2)=C_{1}^{*}$ for a smaller $\sigma$ compared with the case where Arrow securities can be traded. This is because that the removal of statecontingent securities can make it impossible for the Foreign country to insure against low consumption in the low state in the second period. So loss aversion means that the Foreign country has to increase savings even for a moderate $\sigma$.

To understand how the general equilibrium outcomes are determined in this bondonly case where the constraint $C_{2}^{*}(2) \geq C_{1}^{*}$ binds, we use the following two diagrams. Figure 4 illustrates the savings behaviour of the RoW when real interest rates are given. Let horizontal axis represent RoW's endowment and consumption in period one, and the vertical those in period two. Point A describes the RoW's first period and average second period endowments, and point B the RoW's first period and second period low state endowments. When the constraint is binding, RoW's first period and second period low state consumption must lie on the 45-degree line OC. The RoW's intertemporal budget constraint involving the low state is simply the condition $C_{1}^{*}+C_{2}^{*}(L) /(1+r)=Y_{1}+Y_{2}^{*}(L) /(1+r)$, represented by a downward sloping line CB going through the endowment point $\mathrm{B}$. The intersection of the budget and the 45degree lines determines the RoW savings, indicated by the horizontal distance $C_{1}^{*} Y_{1}$. As $\sigma$ increases (so point B moves downwards), the RoW savings will go up. 


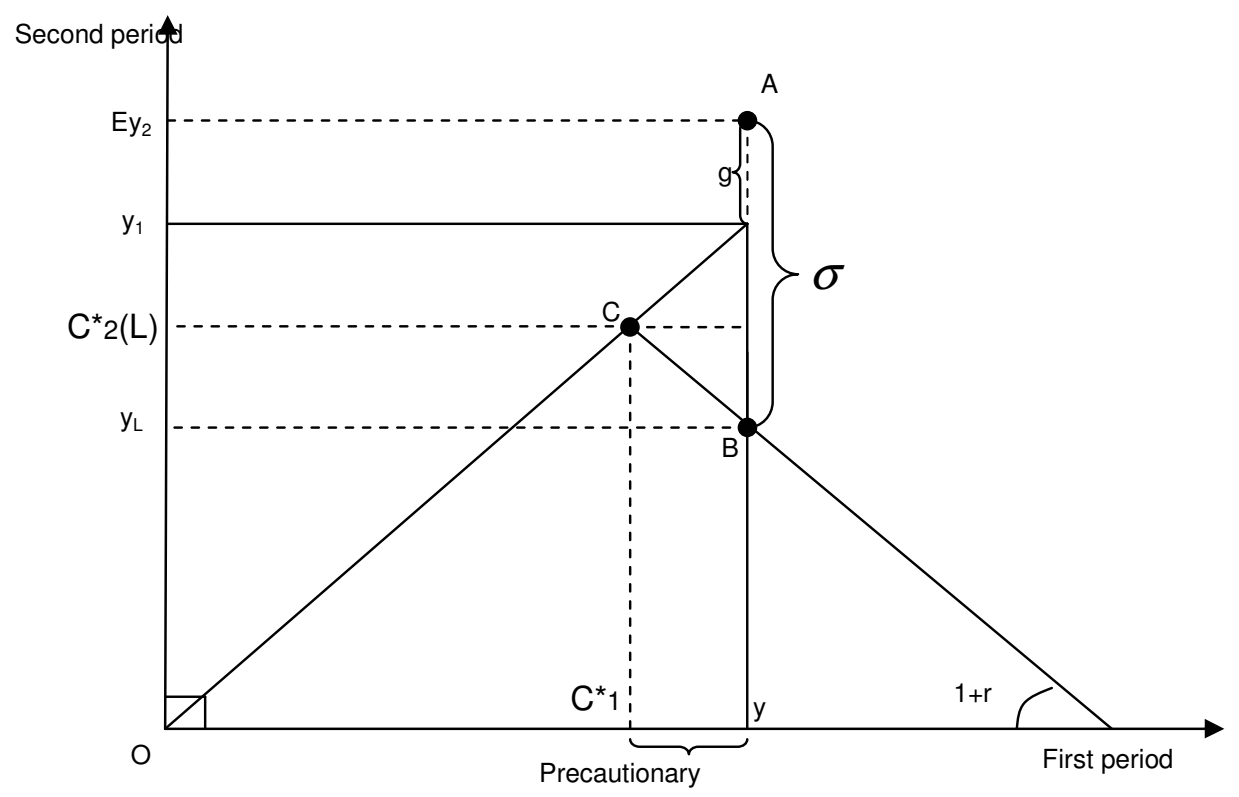

Figure 4: Loss Aversion and Precautionary Saving

As point $\mathrm{C}$ in the Figure is on a budget line which lies $\sigma$ below the usual Fisherian intertemporal budget constraint, so, it appears, loss aversion can generate outcomes observationally equivalent to the lack capitalisation postulated by Caballero et al (2006).

The relationship between the US current account deficit and the real interest rates is illustrated in Figure 5 where horizontal axis represent US endowment and consumption in period one, and the vertical those in period two. Point A describes the US endowments, and the hyperbola AF represents US offer curve. ${ }^{11}$ The intersection of the US budget constraint $\mathrm{AC}$ and the offer curve $\mathrm{AF}$ determines the optimal

\footnotetext{
${ }^{11}$ The parametric representations of the US offer curve is given by the US intertemporal budget constraint and the proportionality condition, $C_{2} / C_{1}=(1+r) \beta$, implied by its first order conditions. Replacing the real interest rates in one of the equations using the other gives the US offer curve.
} 
intertemporal consumption allocation of the US (at point C).

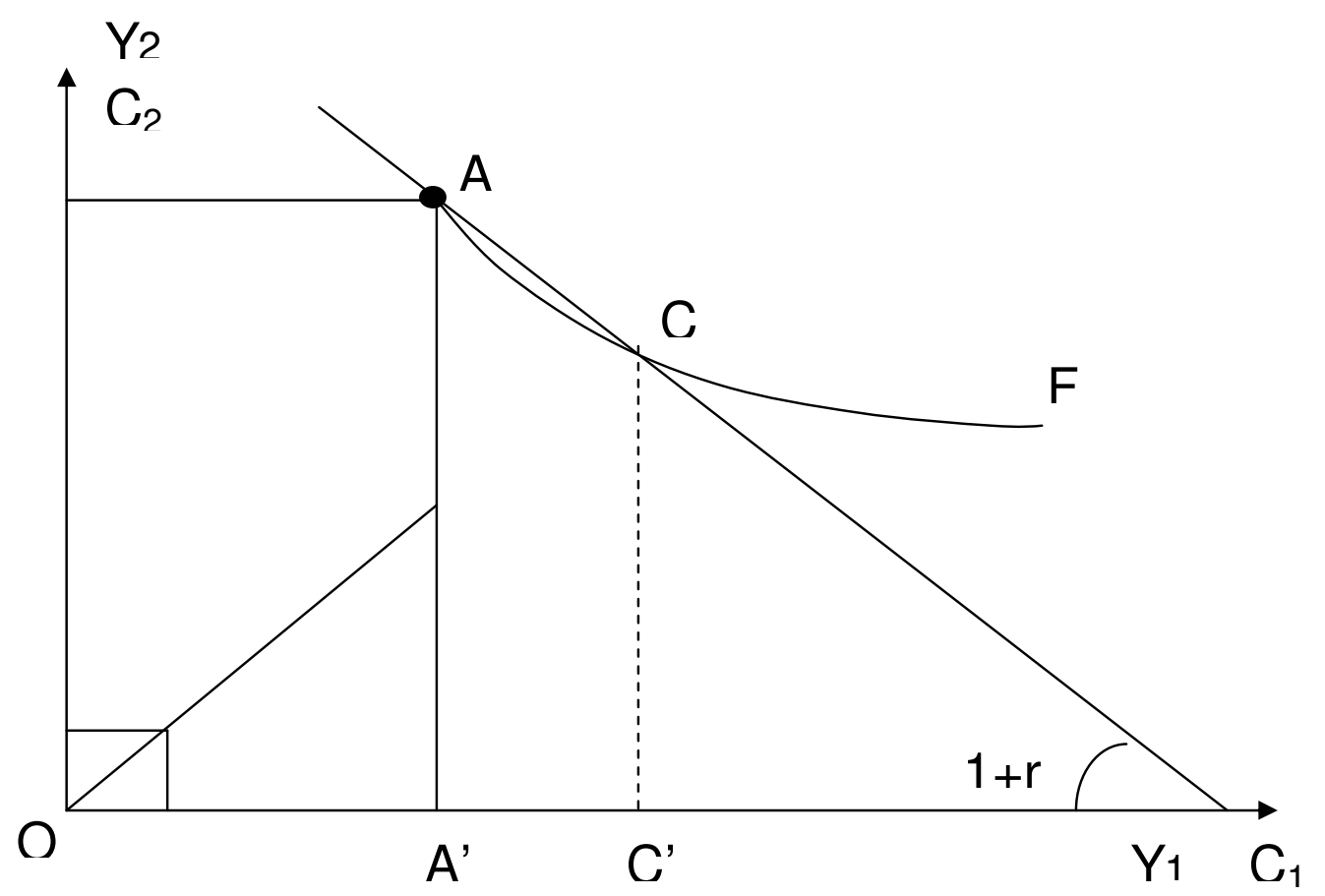

Figure 5 Real interest rates and current account deficits for the US

Since the US first period endowment is at $A^{\prime}, A^{\prime} C^{\prime}$ measures US current account deficit under given real interest rates. It is clear from the figure that a lower real interest rate (budget line rotates anti-clock-wise around A) gives arise to a higher US current account deficit. To determine the equilibrium, one has to vary the real interest rates such that the RoW's savings equals the US current account deficits. When the equilibrium real interest rate is determined, one can use Figures 4 and 5 to back out consumption.

With this by way of background, we address the question of what happens to real interest rates in general equilibrium where the Loss Aversion constraint is binding.

Proposition 5. Given the endowment structure specified in Table 2, for $\sigma \geq(2-2 \beta) /(1+\beta)+[2 /(1+\beta)+1] g$ the real interest rates $r \leq 0$.

Proof: From (14), imposing the condition $r \leq 0$, one obtains the parameter restriction given in the above proposition. 


\begin{tabular}{|c|c|c|c|c|c|}
\hline & $\begin{array}{l}\text { Arrow - Debreu } \\
\text { (with insurance) }\end{array}$ & $\begin{array}{l}\text { RoW Saving/ } \\
\text { US deficit }\end{array}$ & Bonds only & $\begin{array}{c}\text { Real Interest } \\
\text { Rates }\end{array}$ & $\begin{array}{c}\text { RoW Saving/ } \\
\text { US deficit }\end{array}$ \\
\hline$\sigma=3$ & No & $0.01 \%$ & No & $4.5 \%$ & $0.02 \%$ \\
\hline$\sigma=6$ & No & $0.04 \%$ & Binding & $1.5 \%$ & $1.5 \%$ \\
\hline$\sigma=12$ & Binding & $\begin{array}{l}1.2 \% \\
0.3 / 4.0\end{array}$ & Binding & $-4.3 \%$ & $4.6 \%$ \\
\hline$\sigma=18$ & Binding & $\begin{array}{ll}2.5 \% & 0.7 \\
13.4 & \end{array}$ & Binding & $-9.8 \%$ & $7.9 \% 5.0$ \\
\hline
\end{tabular}

Table 6. Savings and real interest rates with loss aversion and no insurance.

As shown in the last column of Table 6, savings rises almost linearly with the measure of risk. Savings reaches $4.6 \%$ for $\sigma=12 \%$, for example, more than 3 times what is necessary with proper insurance ${ }^{12}$. Could it be that the lesson countries like China drew from the East Asian financial crisis was that effective insurance was not available and high savings were the only way to avoid unacceptable reductions in living standards?

The second to last column of Table 6 shows how the real interest rates fall when risk increases. For $\sigma=12 \%$, real interest rate becomes negative. The relationship between real interest rates and risk is illustrated in more detail in Figure 7 where the horizontal axis measures the standard deviation of Foreign period 2 endowment and the equilibrium real interest rates is plotted on the vertical axis. When the loss aversion constraint is not binding real interest rates decreases very slowly with increasing $\sigma$; but when the loss aversion constraint is binding the real interest rates fall sharply as risk increases. From Proposition 5, the critical level of $\sigma$ beyond which the real interest turns negative turns out to be about $7.5 \%$ for the parameters used here.

\footnotetext{
${ }^{12}$ Note that in their paper on the optimal level of international reserves for emerging market countries, Jeanne and Ranciere (2005) assume a crisis output cost of $10 \%$ in their benchmark calibration.
} 


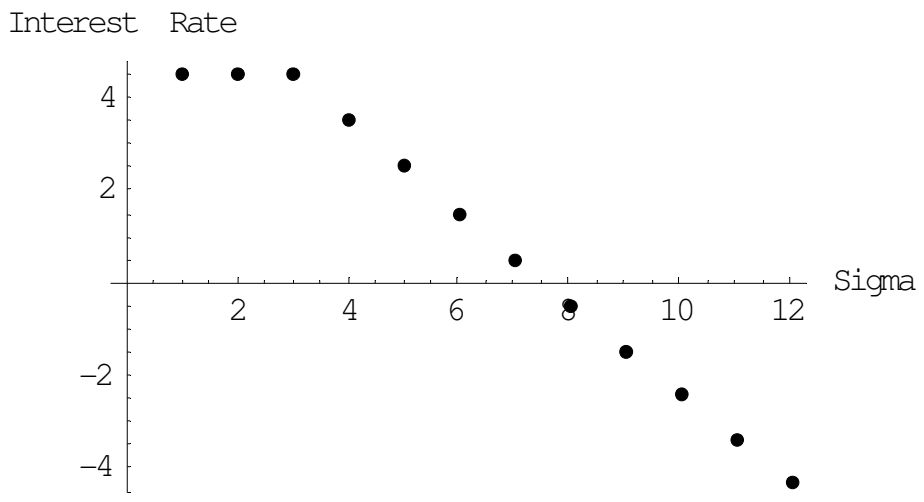

Figure 7. Real interest rates and risk: numerical results.

Possible ramifications of negative real interest rates are discussed in conclusion. Here we note how the availability of insurance can economise on savings. Where the shocks are small enough not to trigger Loss Aversion savings remains largely unaffected by risk. But when Loss Aversion is binding about half the risk is covered by insurance, with the rest triggering extra savings. To take an example, consider the case where $\sigma=0.12$. The formula used above to capture the effects of Loss Aversion, but assuming half the downside risk is insured, becomes $C_{1}^{*}+C_{2}^{*}(L) /(1+r)=Y_{1}^{*}+Y_{2}^{*}(L) /(1+r)$ where $\mathrm{C}_{2} *(\mathrm{~L})=\mathrm{Y}_{1} *(1+\mathrm{g}-\sigma / 2)$, with the result that savings should be approximately $(\sigma / 4-\mathrm{g} / 2)=0.015$, where for simplicity the effect of the interest rate is ignored. This is to be compared with savings rate when there is no insurance, which is approximately $(\sigma / 4-\mathrm{g} / 2)=0.045$, i.e. three times as great. In the next section, we discuss the idea that the supply of insurance may be subject to strategic restriction.

\section{Strategic considerations}

Calculations reported above all assume competitive equilibrium even when the set of assets is incomplete. But, as Dooley and Garber (2005) point out, the big players in asset markets are governments who can manipulate supply. Furthermore, Meissner and Taylor have shown how Britain in the years 1870--1913 and US in years 1981 --2003 have been able to enjoy a "privilege" in the form of higher yields earned on external assets than paid on external liabilities, worth about $0.5 \%$ of GDP per annum 
in both cases. To use the terminology of Hausmann and Sturzenegger (2005), this looks like the "dark matter" which allows the US to sustain substantial portfolio imbalance. (But Meissner and Taylor warn that such monopoly power is a fading asset: the privilege is much higher in earlier years compared to the late years.)

Could one modify the competitive equilibrium by allowing for monopoly power on the part of the US? Instead of supplying safe asset on a competitive basis, US could, for example, select the utility maximising point on the demand for safe asset from the RoW: or could it act as a dynamic monopolist ${ }^{13}$ As indicated by Table below this might generate outcomes between limit cases (of complete markets and no insurance) reported in the paper.

\begin{tabular}{|l|l|l|l|}
\hline & Arrow-Debreu & Market power & Self-insurance \\
\hline $\begin{array}{l}\text { Standard (log) } \\
\text { preferences }\end{array}$ & $\begin{array}{l}\text { Low savings } \\
\text { Fair Insurance }\end{array}$ & $\begin{array}{l}\text { More saving } \\
\text { Overpriced insurance }\end{array}$ & $\begin{array}{l}\text { High Precautionary Savings } \\
\text { No insurance }\end{array}$ \\
\hline Loss aversion & $\begin{array}{l}\text { Same as above, } \\
\text { unless binding }\end{array}$ & $\begin{array}{l}\text { High Precautionary } \\
\text { Savings } \\
\text { Overpriced insurance }\end{array}$ & $\begin{array}{l}\text { High Precautionary Savings } \\
\text { No insurance }\end{array}$ \\
\hline
\end{tabular}

Table 7. GE solutions: Is there a place for strategic analysis?

\section{Sustainability: a comparison}

It may be interesting to compare what we get from a general equilibrium approach with results reported in a recent IMF study of the optimal reserves by Jeanne and Ranciere (2005). For an emerging market economy facing a low spread in capital markets, the risk of a 10\% fall in output should, according to Table 3 of their paper, lead to reserve holdings of $9.37 \%$ of GDP. For a country facing a high spread, however, optimal level of reserves falls to only $1.5 \%$ of GDP. Note that, as all these reserves will are used to smooth consumption if there is a shock and they are all reconstituted one period later, it is as if such a shock is associated with a corresponding savings rate lying between one and a half and nine and a half percent of GDP over the period of reserve build up. As there is no insurance in their model, this is to be compared with our bonds-only results, where the build-up of reserve

\footnotetext{
${ }^{13}$ Supplying dollars at high prices as the RoW accumulates reserves, with a dollar devaluation when reserve stock reaches equilibrium, see Section 7.2 below.
} 
assets precedes the crisis. For a shock with a downside of $12 \%$ our figure for savings is about four and a half percent, which is mid-way between the high (of about nine and a half) and the low (of about one and a half) for Jeanne and Ranciere (2006): so it appears the results are broadly comparable.

Two observations may be made --- over the period of time that reserves are built up, and over the implications for sustainability. As a preliminary, note that the actual reserve holdings by China greatly exceed the savings figures just discussed: from around $16 \%$ of GDP in 2000 they almost doubled to reach $29 \%$ in 2003, Jeanne and Ranciere (2006, Table 1). This suggests that treating the issue in a two period context (as the IMF study and we do) is too restrictive. The level of reserves may be built up over a period of two or three years --- and it can be expanded by assets swaps as well as external surpluses, as the case with insurance has shown.

The second observation is that the reserve build-up is essentially a transitional phenomenon: once reserves have reached their desired level, there is no need for high precautionary savings ${ }^{14}$. This has profound implications: high savings, low interest rate outcomes we have studied are not to be thought of as steady-state equilibria, but as temporary phenomena. Putting it more bluntly, the precautionary approach implies that the current pattern of imbalances is not sustainable. What this might mean for global equilibrium is considered in Section 7.2.

\section{The possibility of Keynesian equilibria}

\subsection{The Liquidity Trap}

No matter that RoW saving rises sharply as perceived risk increases, markets will clear so long as the real interest rate is free to adjust. That is the message of the calculations at the end of Section 4: and it seems to suggest that the model we propose, like that of Caballero et al., is one of full employment equilibrium, loss aversion or no.

\footnotetext{
${ }^{14}$ We can show this in the GE context by changing the initial holding of bonds by the RoW, which play the same role as reserves as in the analysis of Jeanne and Ranciere (2006).
} 
It was found, however, that market-clearing interest rates have to be negative for substantial risk $(\sigma>7.5 \%)$. What if there is a zero lower bound on the real interest rate? This will imply that the US deficit is less than high savings in the RoW in these circumstances: in other words, global demand will fall short of global supply at full employment levels of income.

When might such a bound be relevant? Consider a world with fixed nominal prices and a zero lower bound on the nominal interest rate: in such a world, real rates can be lowered by cutting nominal rates, but they cannot go below zero. (Nor would adding price flexibility help, unless prices are expected to rise.) To focus ideas, consider the case of Japan, where the collapse of the Nikkei in the early 1990s was been followed by a decade or more of inadequate demand with sticky prices and near zero nominal rates.

If one was to impose an exogenous zero bound on the real rates, how is the model to be solved? One will have to make assumptions of what happens when markets do not clear: that supply contracts until global demand and supply balance, for example. Assuming that RoW savings were proportional to its first period income, then a contraction of RoW income e sufficient to cut Row savings to match the US full employment deficit would equate demand and supply. This is, in fact, something like what happened after the East Asian crisis when countries in the region went into sharp recession and the US acted as the 'consumer of last resort'. But if income in both countries can be treated as endogenous, there will be many other equilibria, as there are two variables and only one constraint ${ }^{15}$.

Rather than pursuing this thought experiment much further, it is better to acknowledge that one is re-examining issues at the heart of the debate between Keyes and the Classics. Faced with a rise of savings, Classical economists argued that interest rates would fall as needed to equate savings and investment (and preserve full employment). Keynes objected that interest rates would be subject to a lower bound (set by the Liquidity Trap) and, for this reason, income would become endogenous,

\footnotetext{
${ }^{15}$ It may be tempting, for this reason to aggregate across the two regions and treat the world as a closed economy.
} 
falling until savings matched investment. The Japanese experience has led to a resurgence of interest in Keynesian equilibria, most notably in the 1998 Brookings Paper by Paul Krugman subtitled “Japan's Slump and the Return of the Liquidity Trap"16.

\subsection{A 'Sudden Stop'?}

Given robust expectations of growth, current real interest rates are surprisingly low; but the world is not in a liquidity trap. Nevertheless, the pattern of global imbalances has given economists cause for concern. Does the global model sustain such concern or not? First, we conclude that a pattern of global imbalances where high savings in the RoW is matched by corresponding US deficits is essentially a transitional phenomenon. So some adjustment will have to come.

When reserve positions are adequate, there will be no need for additional precautionary saving, and RoW should consume more and the US less. In addition, however, relative prices may need to adjust. This is spelled out in detail in Obstfeld and Rogoff (2005), for example, who argue that the price of US non-traded goods will have to fall sharply relative to RoW nontraded goods, and the relative price of US traded goods will also have to fall. Given the objective of keeping the aggregate price indices constant in each block, they calculate that this translates into a decline of about $30 \%$ in the dollar. In their view, moreover, the perception that the situation is not sustainable and that adjustment requires a fall in the dollar leaves the US vulnerable to a Sudden Stop in capital flows.

No adjustment of relative prices is necessary in our one good model: but what if, nonetheless, there a Sudden Stop were to occur constraining the US to balance its current account? This would of course prevent the US from acting as 'consumer of last resort', and require the RoW to achieve balance on its own. If there is a precautionary demand for savings outside the US --- and particularly if there is limited access to insurance markets --- an excess supply of global savings will emerge. But, in a world of low inflation and low nominal rates, the Classical

\footnotetext{
${ }^{16}$ Further analysis of the Japanese experience is provided in Aikman and Svennson,
} 
argument that the implied shortage of global demand can be remedied by an appropriate lowering of interest rates lacks conviction. We have seen that a Liquidity Trap could, in principle, prevent this adjustment even where the US is free to act as 'consumer of last resort': how can it be relied to work on in circumstances when the US consumption is checked by financial panic?

\section{Conclusion}

A model of global equilibrium where countries outside the US face higher risk than the US itself can lead to current account surpluses in the RoW. If it is driven by Loss Aversion, such precautionary savings can cause substantial 'global imbalances', particularly if there is an inefficient supply of global insurance. In principle, this simply requires lower real interest rates to ensure that aggregate demand equals supply at the global level (though the required real interest may turn out to be negative). A situation with low interest rates and high savings outside the US thus appears to be an efficient global equilibrium: but is it sustainable?

A precautionary savings glut appears to us to be a temporary phenomenon, destined for correction as and when adequate reserve levels are achieved. In a realistic setting with differentiated traded and non-traded goods, this correction will also require a substantial change in relative prices. So expectations of adjustment may lead to a preemptive Sudden Stop in capital flows to the US, as Obstfeld and Rogoff have suggested.

If the process of correction is triggered by panic, could it not lead to the inefficient outcomes that concern macroeconomists such as Eichengreen and Park, Roubini and Setser, and Martin Wolf? The unprecedented savings levels recorded in East Asia since 1997/8 financial crises and the prolonged failure of Japan to escape from a Liquidity Trap would then appear as early warning signals: and the failure to effect a smooth transfer after the first World War, leading as it did to a Liquidity Trap and the emergence of Keynesian under-employment economics, as a precedent that should not be ignored. Blithe trust in market forces may be misplaced. When precautionary 
savings is combined with financial panic, history offers no guarantee of full employment.

\section{References}

Bailey, A., S. Millard and S. Wells. (2001). "Capital Flows and Exchange Rates." Bank of England Quarterly Bulletin, Autumn: 310-318.

Backus, D; B Routledge, and SE Zin (2004), "Exotic Preferences for Macroeconomists", NBER Working Paper 10597, June.

Backus, David; Espen Henriksen; Frederic Lambert; and, Chris Telmer (2006), "Current Account Fact and Fiction," Working paper, New York University.

Bergsten, Fred and John Williamson (Eds) (2004) Dollar Adjustment: How Far? Against What? IIE:Washington DC.

Buiter, W. (2006), "Dark Matter or Cold Fusion?", Global Economics Paper No: 136, Goldman Sachs. See also: http://www.nber.org/ wbuiter/dark.pdf

Caballero, Ricardo Emmanuel Farhi and Pierre-Olivier Gourinchas (2006), "An Equilibrium Model of "Global Imbalances" and Low Interest Rates", MIT Department of Economics, Working paper: 06-02

Campbell, John Y. and John H. Cochrane (1999), "By Force of Habit: A Consumption-Based Explanation of Aggregate Stock Market Behaviour," Journal of Political Economy, vol. 107 no 2, 205-251.

Carroll, Christopher D., Jody Overland, and David N. Weil (2000), "Saving and Growth with Habit Formation," American Economic Review, vol. 90 no 3, 341-355.

Chari, V. V., Patrick J. Kehoe, and Ellen McGrattan (2002), "Can Sticky Price Models Generate Volatile and Persistent Real Exchange Rates?" Review of Economic Studies, vol. 69 no 3, 533-563

Cooper, Richard (2005), "Living with Global Imbalances: A Contrarian View", Policy Briefs in International Economics, IIE. November.

Dooley, Michael, David Folkerts-Landau and Peter Garber (2004) "The revived Bretton Woods system," International Journal of Finance \& Economics, vol. 9(4), pages 307-313.

Dooley, Michael and Peter Garber, (2005) "The cosmic risk: an essay on global imbalances and treasuries," Proceedings, Federal Reserve Bank of San Francisco, issue Feb. 
Driffill, J. and A. and Snell (2003), "What moves OECD real interest rates?", Journal of Money, Credit and Banking, vol. 35 no 3, 375 - 402.

Eichengreen, Barry and Yung Park (2006) "Global Imbalances: Implications for Emerging Asia and Latin America". Presented at "Global Imbalances and Risk Management Has the center become the periphery?", Madrid, May.

Gourinchas, P. and H. and Rey (2006), "From World Banker to World Venture Capitalist: US External Adjustment and the Exorbitant Privilege", In Richard Clarida, ed., G7 Current Account Imbalances: Sustainability and Adjustment, University of Chicago Press, forthcoming.

Griffith-Jones, Stephany and Krishnan, Sharma (2006) "GDP-Indexed Bonds: Making it Happen". DESA Working Paper No. 21, Department of Economic and Social Affairs.

Griffith-Jones, Stephany and Robert Shiller (2006), "A bond that insures against instability", Finacial Times, July $10^{\text {th }}$.

Hanson, James (2006) "Global Imbalances:Resolving the US Peso Problem" Presented at "Global Imbalances and Risk Management Has the center become the periphery?", Madrid, May.

Hausmann, R. and F. Sturzenegger. 2005. "Global imbalances or bad accounting? The missing dark matter in the wealth of nations." Mimeo, Harvard University.

Jeanne, Olivier and Romain Ranciere (2006) "The Optimal Level of International Reserves for Emerging Market Economies: Formulas and Applications", Mimeo IMF

Kahneman, D., \& Tversky, A. (1979) "Prospect theory: An analysis of decision under risk". Econometrica, 47, 263-291.

King, Mervyn (2006), "Reform of the International Monetary Fund", speech at the Indian Council for Research on International Economic Relations (ICRIER) in New Delhi, India. 20 February.

Kohlscheen, Emanuel and Mark Taylor (2006) "International Liquidity Swaps: Is the Chiang Mai Initiative Efficiently Pooling Reserves?” Mimeo University of Warwick

Krugman, Paul (1998) “It's Baaak:Japan's Slump and the Return of the Liquidity Trap” Brookings Paer s on Economic activity, No.2, pp 137-205.

Lane, P. R. and G. M. Milesi-Ferretti (2004), "Financial globalization and exchange rates." CEPR DP: No. 4745.

Meissner, Christopher and Alan Taylor (2006), "Losing our Marbles in the New Century? The Great Rebalancing in Historical Perspective" Mimeo, Cambridge. 
Miller, Marcus, Olli Castren and Lei Zhang (2005), "Capital flows and the US 'New Economy': consumption smoothing and risk exposure”. ECB Working Paper No. 459 (March).

Miller, Marcus, Olli Castren and Lei Zhang (2006), "Irrational Exuberance" and Capital Flows for the US New Economy: A Simple Global Model, mimeo, University of Warwick. (Forthcoming in International Journal of Finance \& Economics.)

Nolan, Peter (2004), China at the Crossroads, Oxford: Polity

Obstfeld, M. and K. Rogoff (2005), Foundations of international macroeconomics, Cambridge MA: MIT Press

Obstfeld, M. and K. Rogoff (2005), "Global Current Account Imbalances and Exchange Rate Adjustments", Brookings Papers on Economic Activity.

Ravn, Morten, Stephanie Schmitt-Grohe and Martin Uribe (2004), "Deep Habits", CEPR Discussion Paper 4269

Setser, Brad (2006) "Bretton Woods 2: Is it Sustainable?" Paper presented at "Global Imbalances and Risk Management Has the center become the periphery?", Madrid, May.

Wolf, Martin (2006), "Fixing Global Finance”, SAIS Lecture series, March 28-30.

\section{Appendices: available upon request from authors.}

